\title{
70 ÉVES A MECHANIKAI TECHNOLÓGIAI TANSZÉK, AZ ANYAGSZERKEZETTANI ÉS ANYAGTECHNOLÓGIAI INTÉZET
}

\author{
Lukács János \\ egyetemi tanár, intézetigazgató, Miskolci Egyetem, Anyagszerkezettani és Anyagtechnológiai Intézet \\ H-3515 Miskolc-Egyetemváros, e-mail: janos.lukacs@uni-miskolc.hu
}

\begin{abstract}
Absztrakt
A cikk a „70 éves a Miskolci Egyetem Gépészmérnöki és Informatikai Kara” cimü Kari Jubileumi Emlékülés Anyagszerkezettani és Anyagtechnológiai Szekciójában elhangzott elöadás szerkesztett és kismértékben kibövitett változata. Különbözö tárgykörök, így a szervezeti keretek, a fizikai elhelyezkedés, a képzés, a laboratóriumi háttér és a publikációs tevékenység alapján mutatja be a Mechanikai Technológiai Tanszék, illetve az Anyagszerkezettani és Anyagtechnológiai Intézet sokrétü tevékenységét.
\end{abstract}

Kulcsszavak: Nehézipari Müszaki Egyetem, Mechanikai Technológiai Tanszék, Miskolci Egyetem, Anyagszerkezettani és Anyagtechnológiai Intézet

\begin{abstract}
The article is an edited and slightly expanded version of the presentation held in the Materials Science and Technology Session at the Jubilee Conference called „,70th Anniversary of the Faculty of Mechanical Engineering and Informatics of the University of Miskolc". The paper introduces the complex activity of the Department of Mechanical Technology and the Institute of Materials Science and Technology, respectively, based on institutional frames, physical locations, educational activities, laboratorial background, and different types of publications.
\end{abstract}

Keywords: Technical University for Heavy Industry, Department of Mechanical Technology, University of Miskolc, Institute of Materials Science and Technology

\section{Bevezetés}

Amint azt a cím is mutatja, az egykori Mechanikai Technológiai Tanszék (MTTsz) jelentős szervezeti átalakuláson átesve müködik napjainkban. Jelen közlemény a korábbi gyakorlattal, vagyis a hasonló tartalmú írásokkal szakítva, nem pusztán időrendi sorrendben tekinti át a teljes 70 esztendőt, hanem különböző tárgykörök - így szervezeti keretek, fizikai elhelyezkedés, képzési szerkezet és oktatási tevékenység, laboratóriumi háttér, jegyzetek, tankönyvek, szakkönyvek és publikációk - alapján. Nem tárgyalja ez a közlemény a hazai és a nemzetközi kutatások, kutatási együttmüködések témakört, arról Prof. Dr. Tisza Miklós „Hazai és nemzetközi kutatások, kutatási együttmüködések a Mechanikai Technológiai Tanszék, valamint az Anyagszerkezettani és Anyagtechnológiai Intézet 70 éves történetében" címü cikkében olvashatunk.

Ugyanakkor, a közlemény hivatkozik azokra a folyóirat lapszámokra és kiadványokra, amelyekből a Mechanikai Technológiai Tanszék, illetve Anyagszerkezettani és Anyagtechnológiai Intézet (ATI) teljes története részletesebben is megismerhető, a töretlen fejlődés és a végzett munka nyomon követhetö. 


\section{A Tanszék és az Intézet története}

\subsection{Szervezeti keretek}

A Mechanikai Technológiai Tanszék a Nehézipari Műszaki Egyetem (NME) Gépészmérnöki Karának (GÉK) 1949-es miskolci alapítását követő évben, 1950. február 4-ei alapítási dátummal jött létre. 1952-ben kivált a Tanszékből az akkori Mechanikai Technológiai II. Tanszék, amelyből később az egykori Gépgyártástechnológiai Tanszék (ma Gyártástudományi Intézet) és az egykori Szerszámgépek Tanszéke (ma Szerszámgépészeti és Mechatronikai Intézet, illetve Szerszámgépek Intézeti Tanszék) alakult meg. Az 1970-es években, több lépésben alakult ki a Tanszéken belül a szakcsoporti rendszer, a lényegében napjainkig fennálló, anyagvizsgáló, hegesztő, hideg-képlékenyalakító, valamint hőkezelő szakcsoportokkal. Követve az oktatási és a tudományos profilban bekövetkezett változásokat, 1990ben a Nehézipari Müszaki Egyetem neve Miskolci Egyetemre (ME), 2006-ban pedig a Gépészmérnöki Kar neve Gépészmérnöki és Informatikai Karra (GÉIK) változott; e névváltozások nem érintették a Tanszék szervezetét. A 2013-as esztendőben, az egyetemi struktúraváltási program részeként, a Gépészmérnöki és Informatikai Kar tanszéki struktúrája intézeti struktúrává alakult át. Ez a szervezeti változás három módon ment végbe: egyrészt korábbi tanszékek egyesültek intézetekké, másrészt korábbi tanszékek váltak - lényegében változatlan formában - intézetekké, harmadrészt - és ez egyedül a Mechanikai Technológiai Tanszékkel történt így - egy tanszék alakult át két intézeti tanszéket magába foglaló intézetté. A 2013. november 1-jétől múködő Anyagszerkezettani és Anyagtechnológiai Intézet tehát a Mechanikai Technológiai Tanszék jogutódja. Az Intézet két intézeti tanszékből áll. Az egyik a Mechanikai Technológiai Intézeti Tanszék, amely tevékenységében és nevében is utal az 1950-es alapítás óta eltelt időszakra; a másik a Szerkezetintegritási Intézeti Tanszék, amely az első - és tudomásunk szerint napjainkig egyetlen - ilyen nevü egység a hazai felsőoktatásban, és amelynek tevékenysége a nevével jelzett, integráló jellegü diszciplínára fókuszál.

A Tanszék keretei között három további kutatási csoport is müködött. 1958-ban, a Magyar Tudományos Akadémia (MTA) kezdeményezésére, Nehézgépészeti Akadémiai Munkaközösség jött létre az egyetemen. Ennek a Munkaközösségnek, amely több tanszékhez tartozott, és amelyet ma interdiszciplináris kutató teamnek hívnánk, a vezetését a Tanszék mindenkori vezetője látta el. A Munkaközösség 1978-ban, átszervezés következtében megszünt, munkatársai TKFA kereten és az illetékes tanszékek státuszain folytatták tevékenységüket. 1970-ben jött létre a Gépipari Technológiai Intézet (GTI) hegesztő kutatócsoportja, amely 1995-ig müködött, továbbá 1996 és 2003 között a Tanszék adott keretet és helyet az MTA-ME Mechanikai Technológiai Kutatócsoportnak (MTK).

A Mechanikai Technológiai Tanszéket az 1950-es alapítás és 1968 között Prof. Dr. Zorkóczy Béla (1898. március 3. - 1975. november 18.), 1968 és 1990 között Prof. Dr. Romvári Pál (1929. június 27. - 2008. december 25.), 1991-től a 2013-as átalakulásig pedig Prof. Dr. Tisza Miklós vezette. Az Anyagszerkezettani és Anyagtechnológiai Intézet igazgatója az alapítás évében Prof. Dr. Tisza Miklós volt, 2014. január 1-től ezt a feladatot Prof. Dr. Lukács János látja el. Zorkóczy és Romvári professzorok arcképét az 1. ábrán láthatjuk.

\subsection{Fizikai elhelyezkedés}

Az oktató, nevelő munka megszervezése és megvalósítása a mai Földes Ferenc Gimnázium épületében kezdődött. A Tanszék 1951-ben költözött át az akkor még javában épülő Egyetemvárosba, az akkori fóépület (A/1., régi főépület) oldalszárnyába (ma A/2. épület, Kőolaj és Földgáz Intézet), ahol egyben az első mühely-labor rész is kialakításra került. Az Egyetem, illetve az Egyetemváros folyamatos fej- 
lődése újabb épületek megépítését is eredményezte, így 1960-ban adták át a C/3. mühely-labor épületet, 1963-ban a C/2. mühely-labor épületet, 1966-ban pedig az új föépületet (A/4. épület). A Tanszék ezek következtében került a jelenlegi helyére, az új fóépület földszintjére és alagsorába, a $\mathrm{C} / 2$. mühely-labor épület egyik hajójába (4. hajó, északi oldal), a $\mathrm{C} / 3$. mühely-labor épület három hajójába (5., 6. és 7. hajók), megtartva egy laboratóriumi egységét a régi fóépületben (A/1. épület) is.
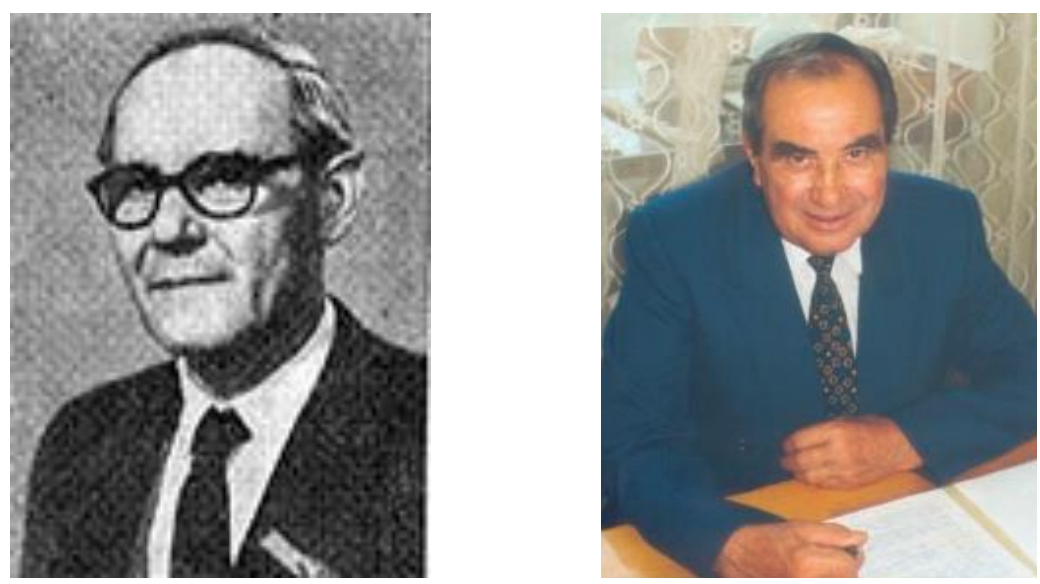

1. ábra. Prof. Dr. Zorkóczy Béla [1] és Prof. Dr. Romvári Pál.

Az A/4. épület teljes átalakítása és megújítása 2015-re fejeződött be, amelynek során a Tanszék újabb alagsori helyiségeket kapott, egyúttal átadta az $\mathrm{A} / 1$. épületben még meglévő laboratóriumi egységét. A C/2. épület első - ház a házban koncepció szerinti - átalakítására 2008-ban került sor, ekkor a Tanszék új, kisebb hallgató létszámok befogadására alkalmas tantermekhez jutott. Az épület 2012-ben lezajlott második átalakítása során a mühely részek megújítására került sor, ekkor a Tanszék megvált az elavult berendezéseinek és eszközeinek jelentős részétől. Az épület 2019-re befejeződött harmadik átalakítása annyiban érintette akkor már az Intézetet, hogy egyes, lényegében kihasználatlan helyiségeket átadott a Felsőoktatási és Ipari Együttmüködési Központnak (FIEK). Ugyanez történt a C/3. épület 6. hajójával is, szintén 2019-ben.

\subsection{Képzési szerkezet és oktatási tevékenység}

A hagyományos, öt éves, illetve 10 féléves gépészmérnök-képzés szakon, majd szakokon folyó képzés volt. 1970-ben átfogó tantervi reformra került sor a Gépészmérnöki Karon, amelynek keretében kialakult annak a három ágazati iránynak - hegesztő, hideg-képlékenyalakító, hőkezelő - a képzési struktúrája is, amelynek a vezetője a Tanszék lett. Az 1980-as évtized második felére, egy újabb oktatási reform eredményeként, kialakításra és bevezetésre került a moduláris rendszerü oktatás. Ebben a Tanszék három fömodul, az anyagtudományi, a hegesztéstechnológiai és a képlékenyalakítási fömodul vezetője lett, továbbá több fö- és mellékmodulban vállalt kisebb-nagyobb szerepet. Az évtized közepétől megindult angol nyelvủ képzés (jordániai hallgatók), újabb oktatási feladatokat jelentve, így a Tanszék tárgyainak egy része ezen az oktatási palettán is megjelent.

A XXI. század első évtizedének legfontosabb változását, nemcsak a Tanszék, hanem az egész magyar felsőoktatás életében is, a bolognai rendszerü képzés bevezetése jelentette. A korábbi, osztatlan egyetemi képzést az alap- és mesterképzés (BSc és MSc, 7 féléves és 4 féléves) rendszere váltotta fel, mindkét szinten szakirányokkal. A BSc szintü képzés a Karon a 2005/2006. tanév első félévében, tehát 
2005 szeptemberében indult, a Tanszék az anyagtechnológiai szakirány gondozója lett, és napjainkban is az. Az MSc szintü képzés, értelemszerüen később, a 2008/2009. tanév második félévében, vagyis 2009 februárjában kezdődött, amelyben a Tanszék az alkalmazott anyagtudományi, az anyagtechnológiai, valamint a hegesztéstechnológiai szakirányok vezetője lett, és további jelentős szerepet vállalt a CAD/CAM szakirányban. A 2010-es évek meghozták az angol nyelvü képzés újabb felfutását (Stipendium Hungaricum (SH)), 2015-ben pedig lezajlott a BSc képzés első reformja. Az MSc tantervek 2011-es áttekintése során a Tanszék az alkalmazott anyagtudományi és az anyagtechnológiai szakirányát egyesítette, korszerủ anyagok és technológiák néven, 2014-ben pedig a megmaradt két szakirányt, anyagtechnológiai és hegesztéstechnológiai szakirány néven. Mindezek közben a szakirány megnevezés specializációra változott. 2019-ben megkezdődött az MSc képzés első reformja.

Hazánkban 1993-tól vezették be, fokozatosan, a doktori ( $\mathrm{PhD}$ ) képzést és fokozatszerzést. A Tanszék a Sályi István Gépészeti Tudományok Doktori Iskola programjában vállalt és vállal jelentősebb szerepet, részt vett és - lényegesen kisebb mértékben ugyan - de ma is részt vesz a Hatvani József Informatikai Doktori Iskola tevékenységében is.

1961-ben, a Tanszék szervezésében és irányításával, hazánkban elsőként elindult a Hegesztő szakmérnök képzés, amelynek az első reformja 1976-ben zajlott le. A nemzetközi elismertetés terén az első lépés 1993-ban történt meg, ekkortól volt lehetőség a Bécsi Hegesztési Intézettel (Schweißtechnische Zentralanstalt (SZA)) közös európai hegesztömérnöki diploma (European Welding Engineer (EWE)) kiadására, amelyre saját jogon - második lépésként - 1998-tól kerülhetett sor. Az évtized végére (2009) a hegesztő szakmérnök képzés Nemzetközi Hegesztő Mérnök (International/European Welding Engineer (IWE/EWE)) képzéssé alakult át.

Az 1980-as évekre kidolgozásra került a Képlékenyalakító szakmérnöki szak tanterve és 1984-ben ezen a szakmérnöki szakon is indult képzés. A 2000-es évek első évtizedének végén a Tanszék bekapcsolódott a Nemzetközi Hegesztett Szerkezet Tervezö Mérnök (International Welded Structures Designer (IWSD)) képzésbe, mind a 2010-ben, mind a 2013-ban indult évfolyamokon oktatta a kompetenciájába eső tantárgyakat. Egy Erasmus ${ }^{+}$projekt keretében részt vettünk a Risk Management in Welding Fabrication (RMWF) képzés tananyagának kidolgozásában (EWF Special Course) és az első két tanfolyam megtartásában, Temesváron és Miskolcon, 2018-ban, angol nyelven. Az ellenállás hegesztés területéröl két szinten, a specialista és a kiemelt hegesztö szintjén (European Welding Specialist for Resistance Welding (EWS-RW) és a European Welding Practicioner for Resistance Welding (EWS-RW)) akkreditáltattunk képzéseket, az első pilot kurzusra 2019-ben került sor.

A jellemzően rövid idejü szakirányú (mérnök) továbbképzések keretében hagyományosnak nevezhető, ismeretmegújító (például ellenálláshegesztés, gázipari felelős mérnök, alakítástechnológiák), valamint új ismereteket adó (például AutoForm rendszer, DEFORM rendszer, szerkezetintegritás) képzéseket tartottunk és tartunk, kezdetben tanszéki szervezésben, majd az egyetemi felnőttképzési szerveztek koordinálásával.

A számítógépek elterjedése és az informatikai technológiák folyamatos fejlődése magával hozta a különböző szintü e-learning módszerek egyetemi képzésbe és továbbképzésbe való integrálódását, amelyben a Tanszék - és így az Intézet is - a kezdetektől fogva aktívan bekapcsolódott.

\subsection{Laboratóriumi háttér}

A Tanszék oktatási-kutatási infrastruktúrájának kialakítása az alapítás pillanatában elkezdődött, szinten tartására, illetve fejlesztésére az új épületek átadásai, az egyes épületek felújításai és - leginkább a különböző pályázatok és projektek nyújtotta lehetőségek szolgáltak. Nem volt olyan projekt, amelynek ne lett volna ilyen eleme és több projekt is szerveződött kifejezetten ilyen szándékkal és célokkal. 
Az 1980-as évek közepétől az informatikai eszközök és a szoftverek beszerzése, fenntartása és megújítása további, nem kis feladatot jelentett és jelent napjainkban is.

Az intézet laboratóriumai, számos átalakuláson átesve, napjainkban a következők:

- Alakítástechnológiai laboratórium;

- Anyagtechnológiai CAD/CAM laboratórium;

- Felületvizsgáló laboratórium (RKI);

- Hegesztéstechnológiai laboratórium;

- Hö- és felületkezelő laboratórium (RKI);

- Komplex mechanikai anyagvizsgáló laboratórium (SKI);

- Termo-mechanikai fizikai szimulációs laboratórium (RKI).

A Nemzeti Kutatási Infrastruktúra Felmérés és Útiterv (NEKIFUT) regiszterben a Komplex mechanikai anyagvizsgáló laboratórium stratégiai kutatási infrastruktúra (SKI), a Termo-mechanikai fizikai szimulációs laboratórium Gleeble 3500-as fizikai szimulátora, valamint a Hö- és felületkezelö laboratórium és a Felületvizsgáló laboratórium együtt, Hőkezelő és Müszaki Felülettudományi Laboratórium néven regisztrált kutatási infrastruktúra (RKI) minősítést szerzett [2].

Fontos sajátossága a kutatási területeknek és témáknak, valamint a kutatási infrastruktúra alkalmazásának az, hogy azokat az Intézet komplex módon közelíti meg, olyan projekteket indít, amelyek több területet és/vagy témakört, illetve témát ölelnek fel. Az infrastruktúrát a két intézeti tanszék közösen használja, aminek egyenes következménye az, hogy az Intézet nem oktató munkatársai mindkét intézeti tanszék feladataiból egyformán veszik ki a részüket.

\subsection{Jegyzetek, tankönyvek, szakkönyvek és publikációk}

A gépészmérnök-képzés kezdetekor a képzés egyetemi jegyzetekkel (kéziratokkal) való ellátása egyformán volt szándék és elvárás. Nyomdailag esetenként nem túl igényes, de viszonylag olcsón előállítható jegyzetek a Tanszék által oktatott minden szakterületen készültek, amelyekre a 2 . ábrán láthatunk példákat.

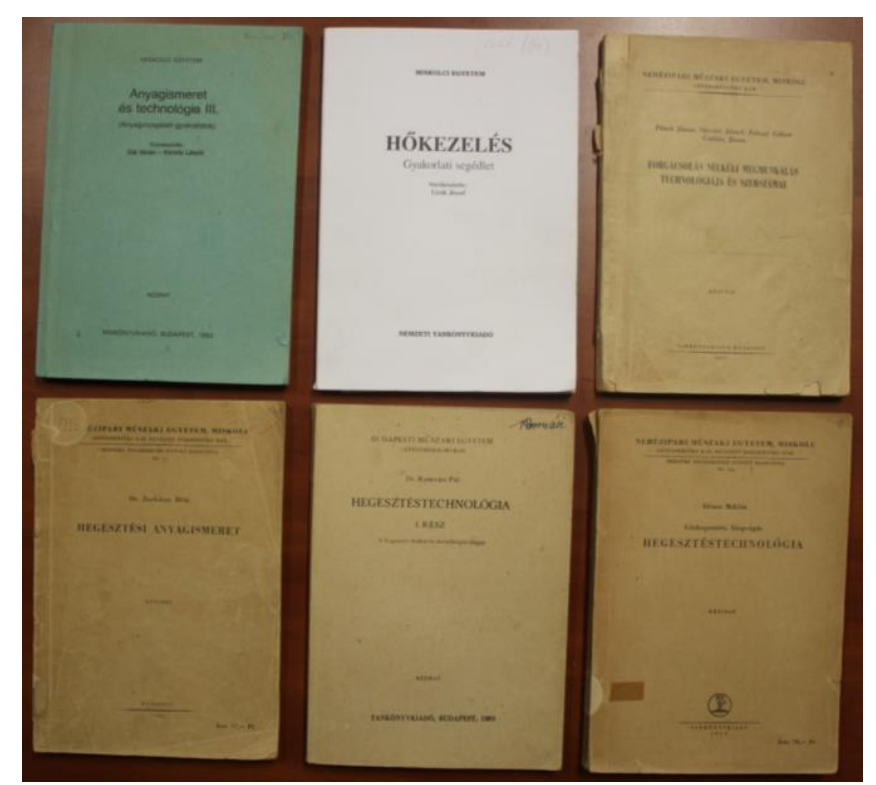

2. ábra. Egyetemi jegyzetek (kéziratok) a Tanszék különböző szakterületeiröl [3]-[8]. 
Az egyes jegyzetek bibliográfiai adatai az Irodalomjegyzékben megtalálhatók, azok címei, balról jobbra és fentről lefelé, a következők:

- Anyagismeret és technológia III. (Anyagvizsgálati gyakorlatok) [3];

- Hökezelés - Gyakorlati segédlet [4];

- Forgácsolás nélküli megmunkálás technológiája és szerszámai [5];

- Hegesztési anyagismeret [6];

- Hegesztéstechnológia - I. rész - A hegesztés fizikai és metallurgiai alapjai (jobb felső sarkán Romvári professzor kézjegyével) [7];

- Gázhegesztés, lángvágás - Hegesztéstechnológia [8].

Az ilyen típusú jegyzetek mellett kiemelkedő jelentőségü volt a (miskolci) gépész generációk által használt Zorkóczy Béla: Metallográfia és anyagvizsgálat [9] címü tankönyv, "a Zorkóczy", amely több évtizeden keresztül alapmünek számított (3. ábra).
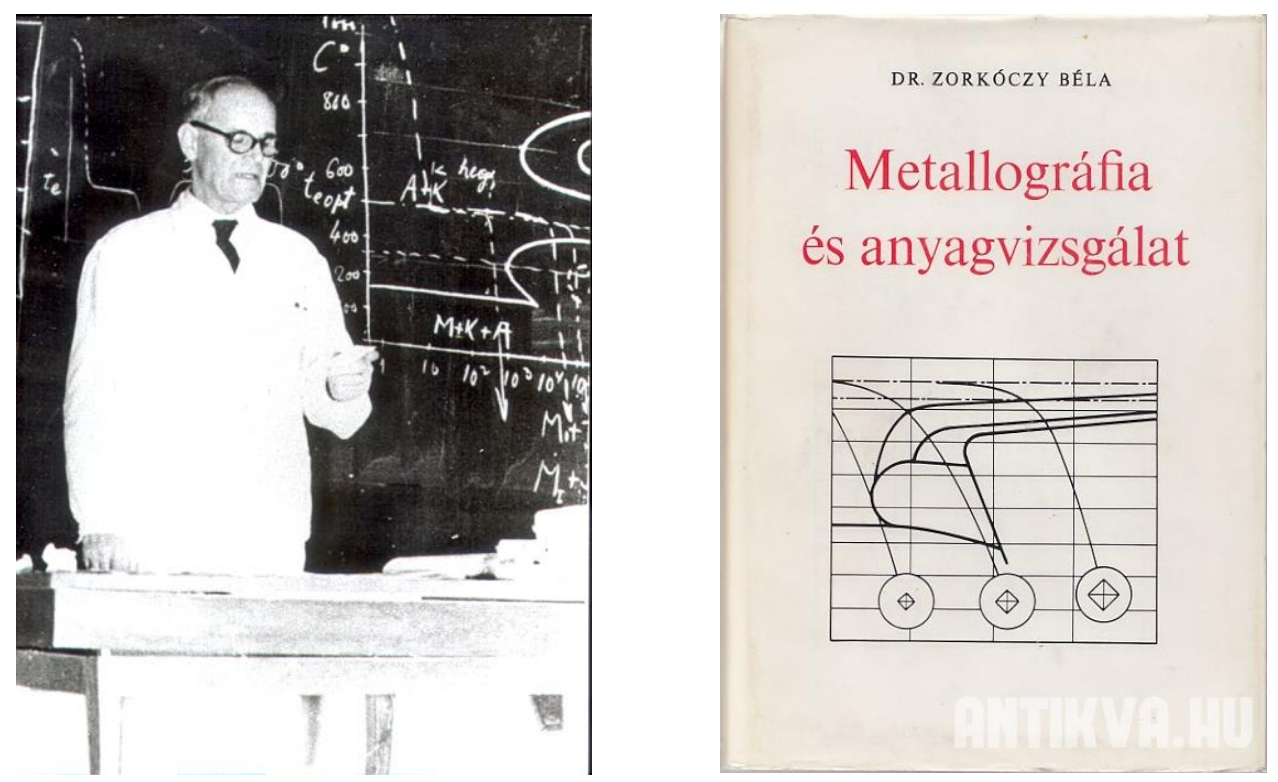

3. ábra. Zorkóczy professzor elöadása és "a Zorkóczy” könyv [9].

A differenciálódó ismeretek, a részben azokhoz is köthető tantervi változások, a megváltozott informatikai, nyomdai és kiadói lehetőségek tartalmilag átfogóbb, formailag pedig igényesebb tankönyvek megírást is lehetővé tették, amelyekre a 4. ábra mutat példákat. Az ábrán látható tankönyvek szerzői és címei, balról jobbra és fentről lefelé, a következők (bibliográfiai adatok az Irodalomjegyzékben):

- Gépipari anyagismeret [10];

- Metallográfia [11];

- Mechanikai technológiák [12];

- Anyagvizsgálat [13];

- Képlékeny hidegalakitás (hagyományos jegyzet) [14];

- Az anyagtudomány alapjai (két különbözö kiadásban) [15]. 


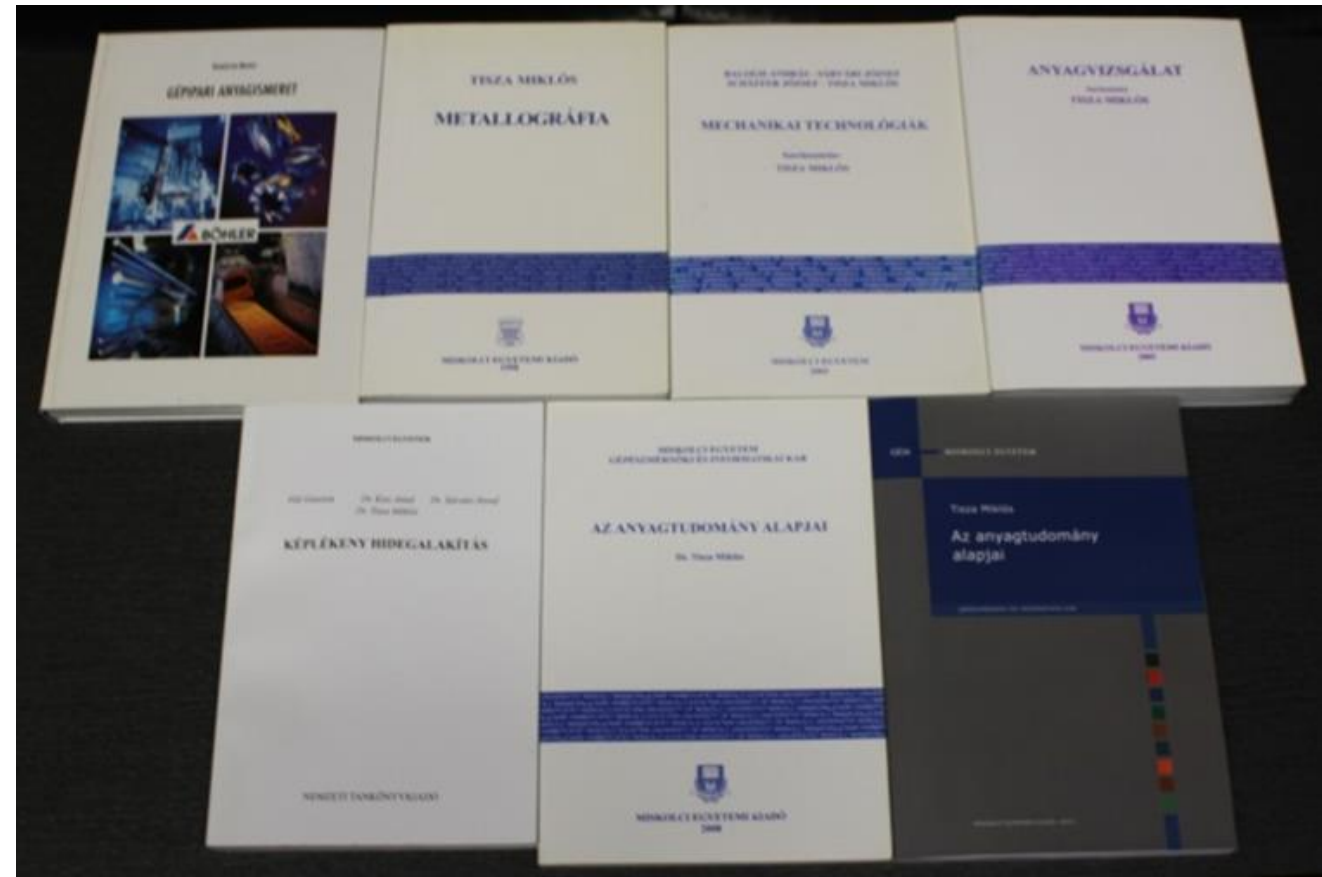

4. ábra. Tankönyvek az 1990-es évek végéröl és a 2000-es évek elejéröl [10]-[15].

Az angol nyelven folyó oktatáshoz is készültek tankönyvek, illetve igazi kuriózum a perzsa nyelven kiadott Tisza Miklós: Physical Metallugry for Engineers [16] címü munka (5. ábra). Az ábrán látható tankönyvek a következők, balról jobbra (bibliográfiai adatok ezúttal is az Irodalomjegyzékben):

- Metal Forming [16];

- Physical Metallurgy for Engineers [17];

- Introduction to Materials Sciences [18];

- Physical Metallurgy for Engineers [19].
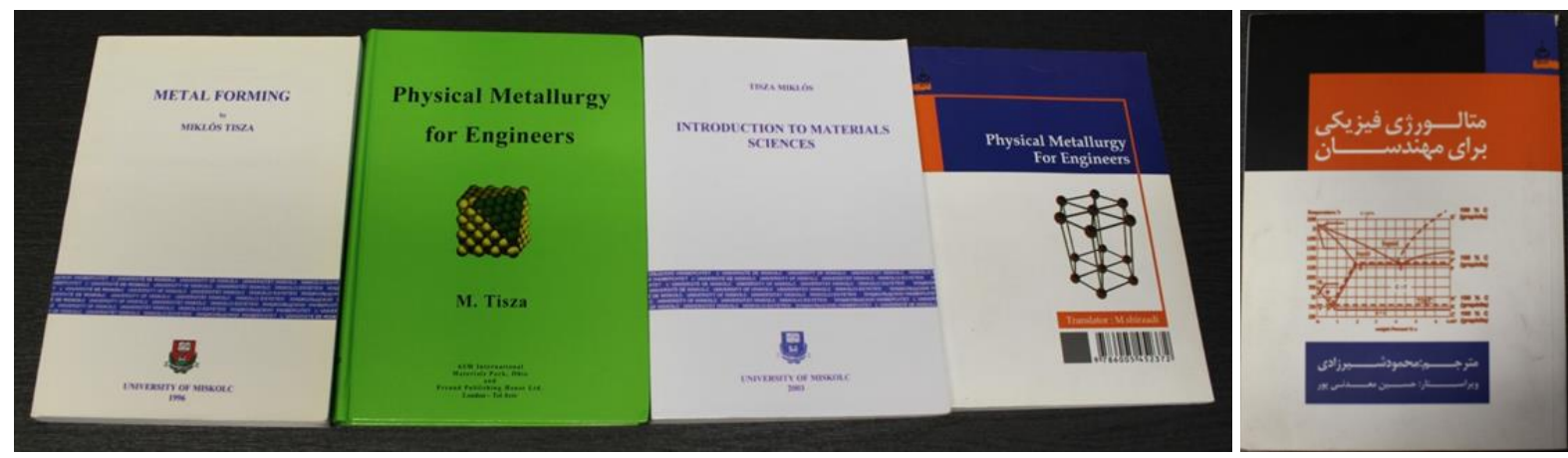

5. ábra. Idegen nyelven megjelent tankönyvek [16]-[19].

Az egyetemi jegyzetek és tankönyvek mellett egy-egy szakterület mélyebb bemutatására adtak lehetöséget a különböző szakkönyvek, kézikönyvek, illetve zsebkönyvek. Ezek címlapjait foglalja össze a 6. ábra [20]-[28]. 

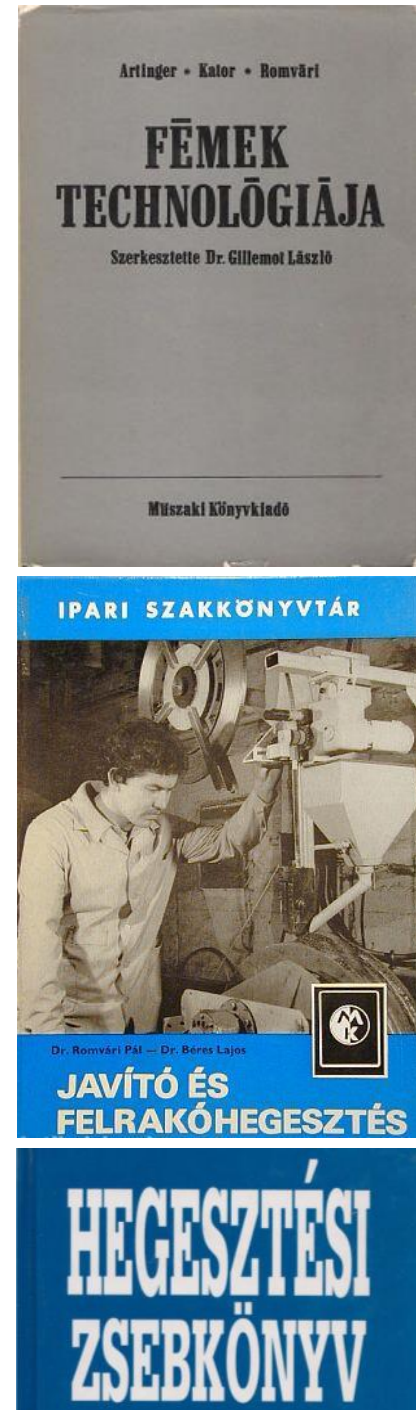

Szerkesztette:

Dr. Gáti József

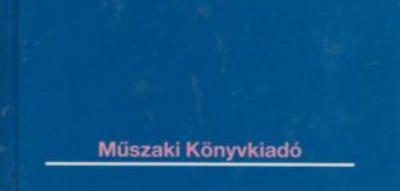

6. ábra. Magyar nyelvü szakkönyve

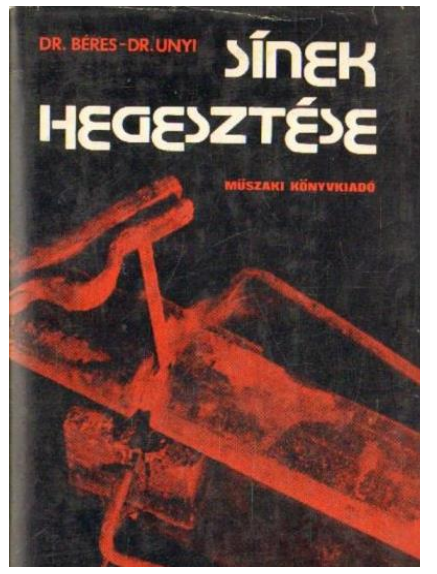

Béres Lajos - Komócsin Mihály

Acélok, öntöttvasak javító- és felrakóhegesztése
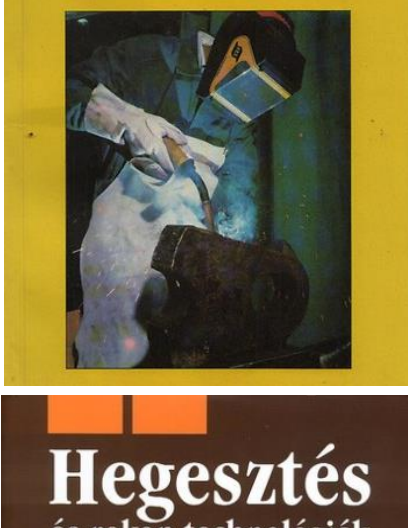

és rokon technológiák

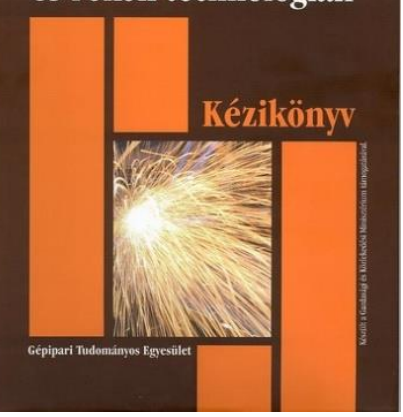

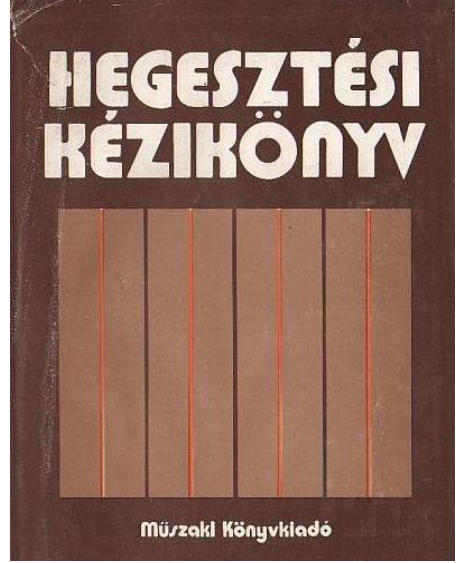

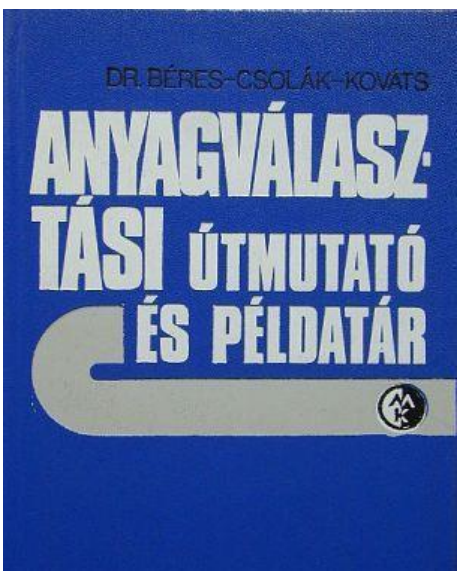

HEGESZTÉSI ZSEBKÖNYV

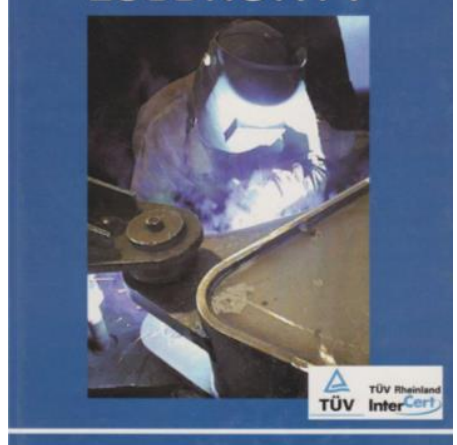

a Tanszék oktatóinak szerzői érintettségével [20]-[28].

A különböző pályázatok - az azok témaköreiből összeállított folyóirat célszámok [29]-[31] mellett - mind szakmai, mind finanszírozási oldalról lehetőségeket kínáltak arra is, hogy a kutatásokról, azok eredményeiről szakkönyvekben adjunk számot, mind a Tanszék / Intézet, mind pedig a résztvevő 
partnerek oldaláró, önálló, illetve közös munkák formájában. A GVOP-3.1.1.-2004-05-0215/3.0 [32] projektben, a Mechatronikai és Logisztikai Rendszerek Regionális Egyetemi Tudásközpont (MLRRET) projektben [33], illetve a TÁMOP-4.2.1.B-10/2/KONV-2010-0001 [34] projekt „Alkalmazott Anyagtudományi és Nanotechnológiai Kiválósági Központ”-jában készült szakkönyvek címlapjait a 7. ábra szemlélteti [35]-[37].

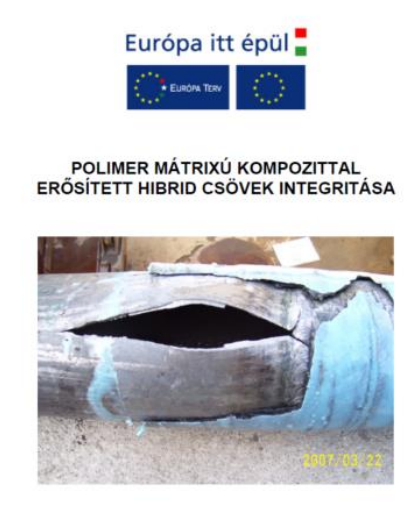

GVOP-3.1.1.-2004-05-0215/3.0
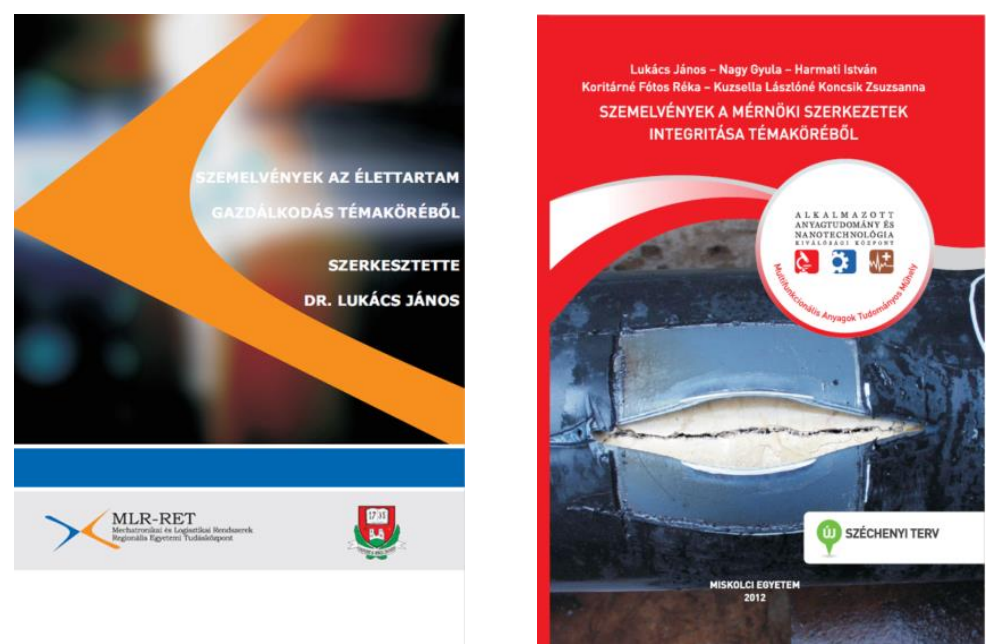

7. ábra. Projekt finanszirozással kiadott, szerkezetintegritás tárgyú könyvek címlapjai [35]-[37]

A TÁMOP-4.2.2.A-11/1/KONV-2012-0029 [38] projekt kutatásainak három fö témakörét a hegesztési, hő- és felületkezelési és alakítási technológiai területeken végzett alapkutatások képezték. A kutató munka egészéről, a projektben végzett tevékenységekről, az egyes tématerületeken elért eredményekröl a projektben készült könyvsorozat [39]-[44] ad teljes képet, a három fö témakör mongráfiáinak a címlapjait a 8 . ábrán láthatjuk.

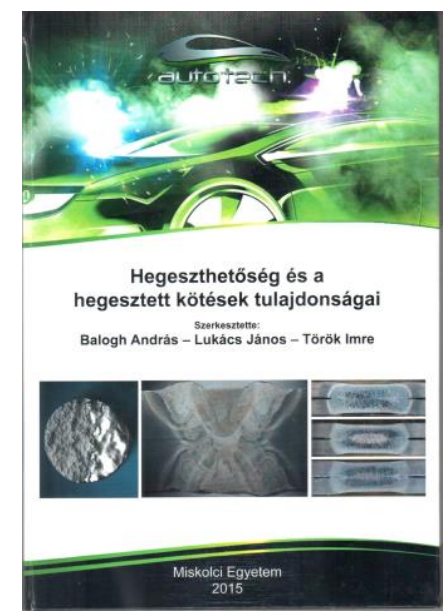

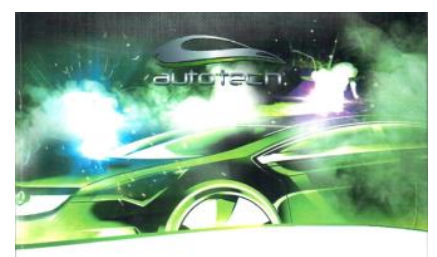

Képlékenyalakitás a jármüiparban Tisza Miklós

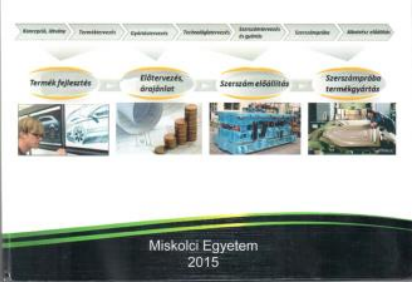

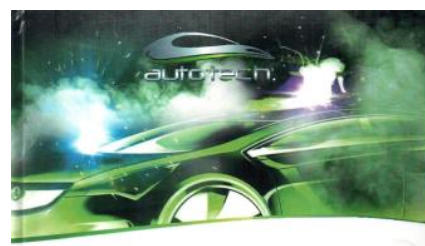

Nitridálás - korszerũ eljárások és vizsgálati módszerek

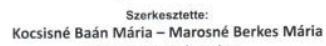
Szilágyiné Biró Andrea
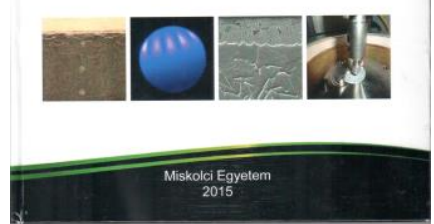

8. ábra. Az Autotech [21] projekt három fö témakörében készült monográfiák címlapjai [39]-[41].

A Tanszék, illetve az Intézet oktatói, kutatói szakmai munkáikról rendszeresen, magyar és idegen nyelvü közleményekben számoltak be. Három kiadvány [45]-[47] összegzi a vonatkozó időszakok 
(1950-1985, 1986-1990 és 1991-1995) tanszéki publikációit, és három további forrásban [48]-[50] találhatunk információkat a publikációs aktivitásról. A Magyar Tudományos müvek Tára (MTMT) [51] 2007-től ad lehetőséget arra, hogy tágabb összefüggésben is elhelyezhessük a Tanszék, majd az Intézet publikációs tevékenységét. A 9. ábra a Miskolci Egyetem, a 10. ábra a Gépészmérnöki és Informatikai Kar, a 11. ábra pedig a Tanszék, majd Intézet publikációs teljesítményét mutatja be, három mutató segítségével. (Az adatok letöltése 2019. december 31-én történt.)

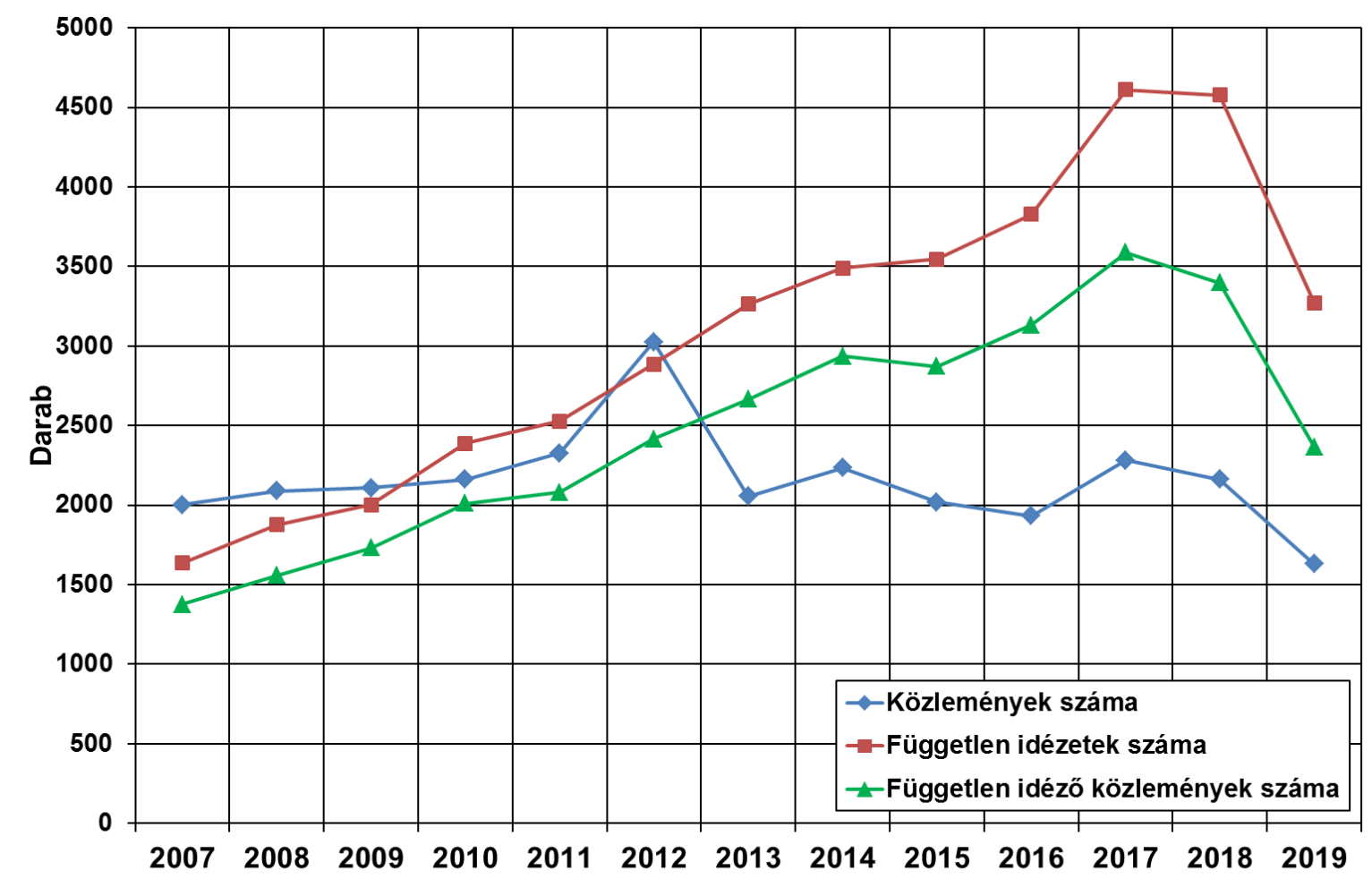

9. ábra. A Miskolci Egyetem publikációs teljesitménye 2007 és 2019 között, a Magyar Tudományos Müvek Tárában [51] található három mutató alapján.

A három ábrához három megjegyzés mindenképpen kívánkozik. Az első az, hogy az adatok abszolút számok, nem veszik figyelembe az aktuális oktatói-kutatói létszámokat; a második az, hogy a 2019-es év adatai biztosan nem tekinthetők véglegesnek; a harmadik pedig az, hogy mélyebb elemzéshez további és/vagy részletezettebb adatok is szükségesek lennének, hiszen itt pusztán mennyiségi mutatókról van szó. A megfogalmazott megjegyzések mellett is megállapítható azonban a hullámzó teljesítmény, valamint az intézményi, a kari és a tanszéki / intézeti adatok tendenciáinak részleges eltérése. 


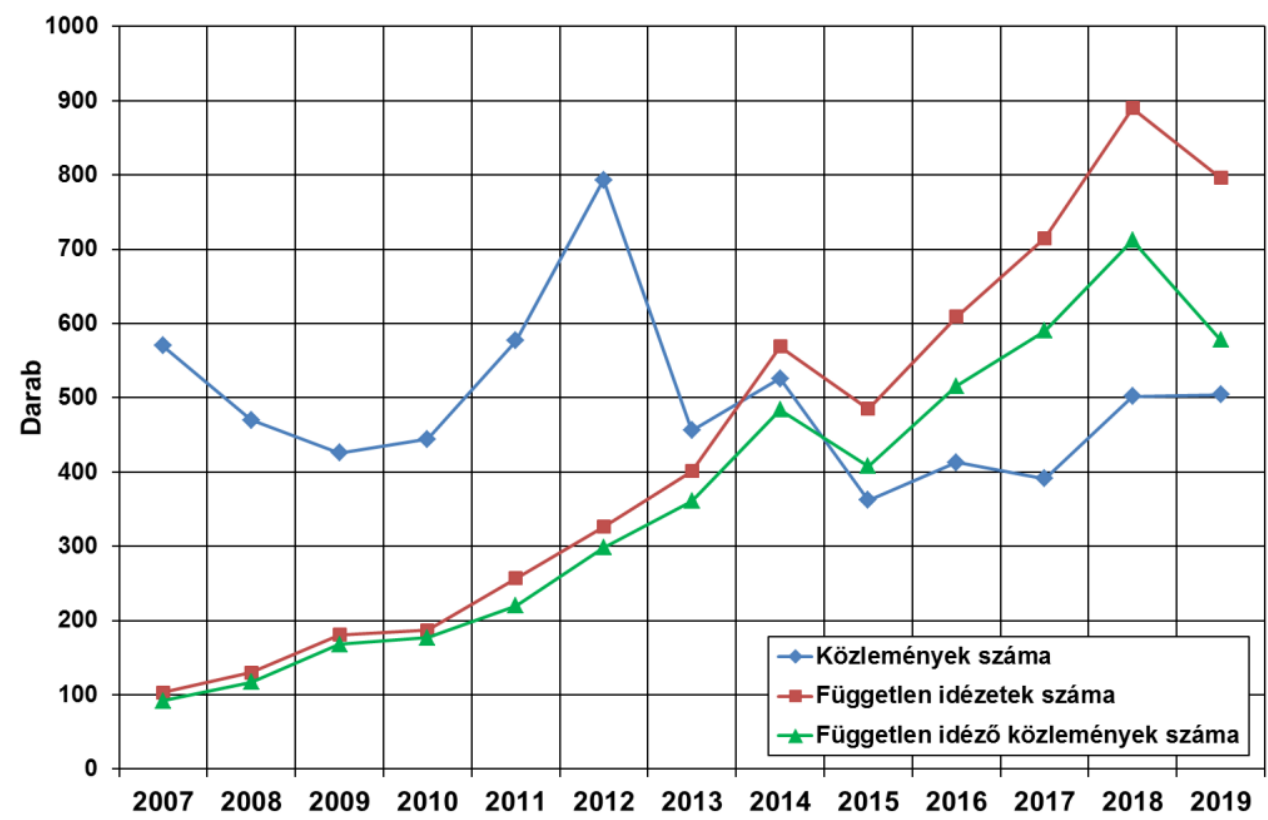

10. ábra. A Miskolci Egyetem Gépészmérnöki Karának publikációs teljesitménye 2007 és 2019 között, a Magyar Tudományos Müvek Tárában [51] található három mutató alapján.

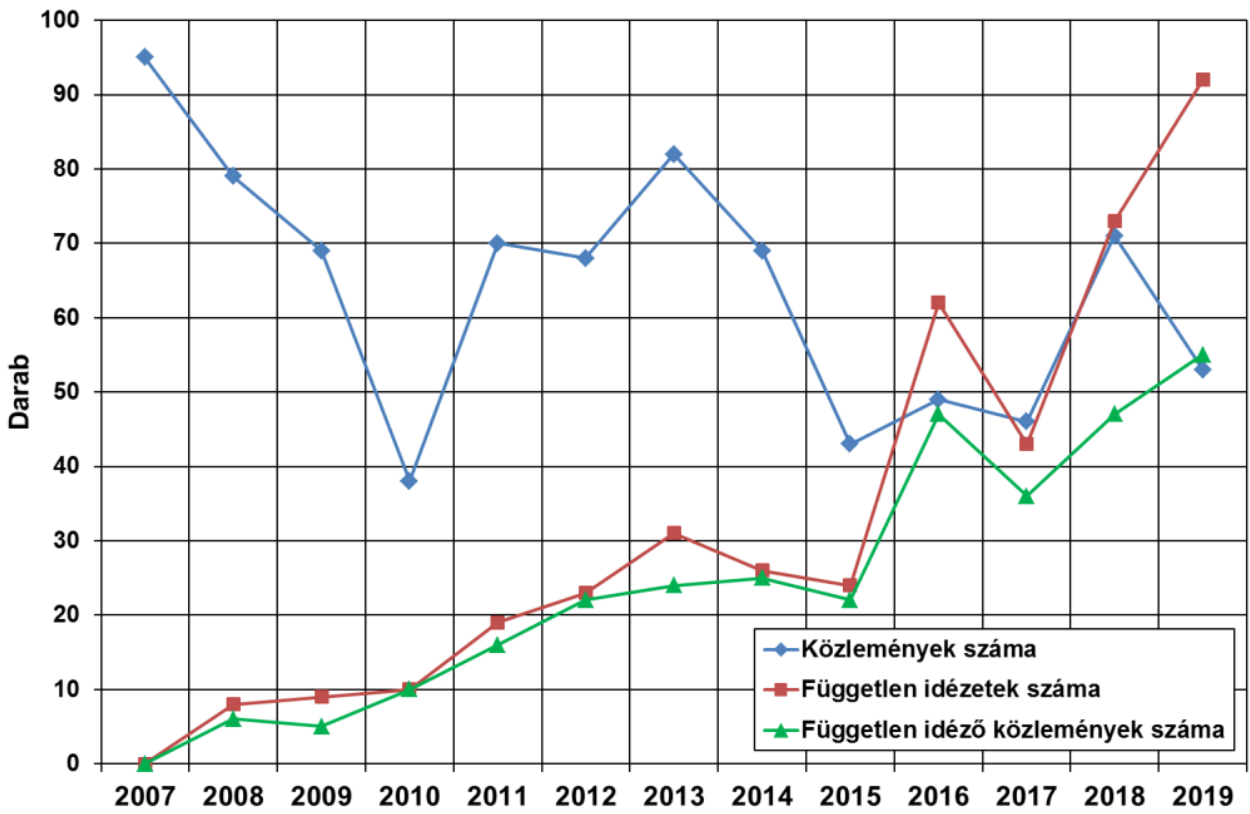

11. ábra. A Miskolci Egyetem Gépészmérnöki és Informatikai Kara Anyagszerkezettani és Anyagtechnológiai Intézetének (korábban Mechanikai Technológiai Tanszék) publikációs teljesítménye 2007 és 2019 között, a Magyar Tudományos Müvek Tárában [51] található három mutató alapján. 


\section{3. Összegzés}

A közlemény különböző tárgykörök - szervezeti keretek, fizikai elhelyezkedés, képzési szerkezet és oktatási tevékenység, laboratóriumi háttér, jegyzetek, tankönyvek, szakkönyvek és publikációk alapján tekintette át a 2020-ban 70 éves Mechanikai Technológiai Tanszék, illetve Anyagszerkezettani és Anyagtechnológiai Intézet történetét. Nem tárgyalta a hazai és a nemzetközi kutatások, kutatási együttműködések témakört, meghagyva annak kifejtését egy másik cikk számára.

A közlemény, minden törekvés ellenére sem lehetett teljes, nem térhetett ki minden részletre. A tanszék és a hegesztő szakmérnök képzés történetéről bővebben olvashatunk az [52]-[55] folyóiratokban, valamint a [48] és a [56] kiadványokban. Újabb részletek ismerhetők meg annak a tudományos emlékülésnek az anyagából [49], amelyre a Miskolci Egyetem alapításának 50 évében, Romvári professzor 70 éves köszöntése alkalmából került sor (1999. június 29.), az ugyanezen alkalomra írott cikkből [57], valamint a Romvári professzor halálakor megjelent méltatásból [58] és a halálának évfordulóján, a tiszteletére megrendezett emlékülés (2010. január 22.) és emlékkiállítás anyagából [59]. További adalékok találhatók abban a kiadványban is [50], amely Béres Lajos, Kovács Ferenc és Pirkó József születésének 70. évfordulója alkalmából megtartott tudományos ülésre (2002. június 6.) készült. Érdekes részletek hangzottak el a "MultiScience - XXX. microCAD International Multidisciplinary Scientific Conference" [60] "Innovative Mechanical Technologies" szekciójának jubileumi köszöntők részében (2016. április 22.) és a "MultiScience - XXXIII. microCAD International Multidisciplinary Scientific Conference" [61] "70th Anniversary of Professor Dr. Miklós Tisza" című tisztelgő szekciójában (2019. május 23.).

A cikk végére kívánkozik az a csoportkép (12. ábra), amely a 70 éves kari jubileumi kiadványba készült, 2019. május 30-án, az Egyetem főbejárata elött.

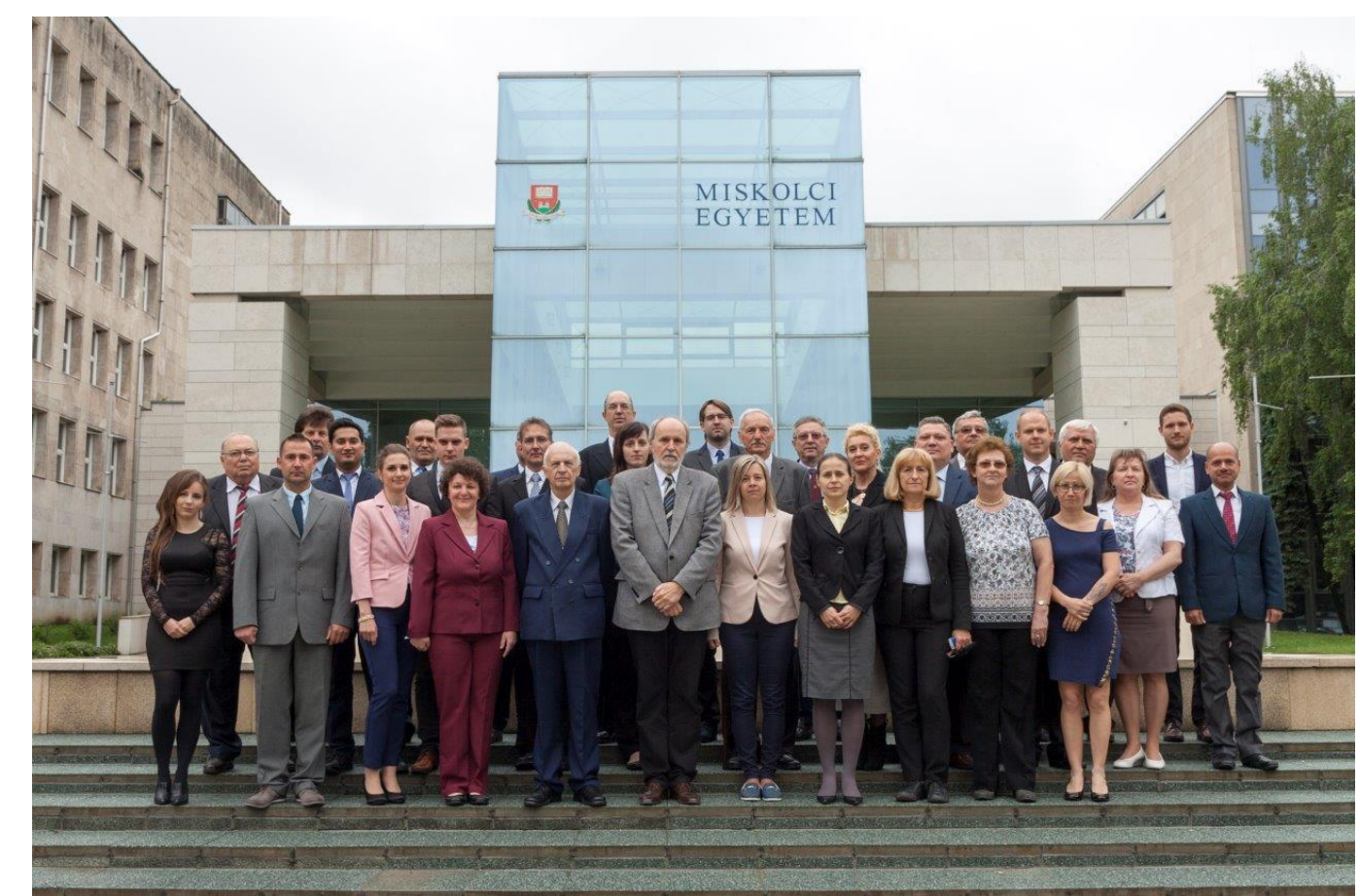

12. ábra. A 70 éves kari jubileumi kiadványba készült intézeti csoportkép (2019. május 30.). 
A fényképen látható személyek, soronként, balról jobbra. Hátsó sor: Bartók András müszaki szolgáltató, Petrovics András müszaki szolgáltató, Kecskés-Kristóf Sándor müszaki ügyintéző (erősen takarva), Szentpéteri László tanszéki mérnök, Dr. Dobosy Ádám adjunktus, Dr. Török Imre c. egyetemi tanár (ny. egyetemi docens), Dr. Nagy Gyula c. egyetemi tanár (ny. egyetemi docens), Dr. Kiss Antal c. egyetemi docens (ny. egyetemi adjunktus), Jámbor Péter (tanszéki mérnök). Középső sor: Dr. Frigyik Gábor ny. egyetemi docens, Shiraz Ahmed Siddiqui PhD hallgató, Gál Viktor tudományos segédmunkatárs, PhD hallgató, Dr. Kovács Péter egyetemi docens, Németh Alexandra Kitti tanársegéd, Dr. Balogh András c. egyetemi tanár (ny. egyetemi docens), Dr. Marosné Dr. Berkes Mária egyetemi docens, Dr. Kuzsella László egyetemi docens, Dr. Gáspár Marcell Gyula adjunktus, Szegeczki Tiborné gazdasági ügyintéző, Raghawendra Pratap Singh Sisodia tudományos segédmunkatárs, PhD hallgató. Első sor: László Noémi tanársegéd, Dr. Lukács Zsolt egyetemi docens, Kőmíves Mariann ügyvivő szakértő, Csurilláné Balogh Ágnes laboráns, Prof. Dr. Tisza Miklós Professor Emeritus, Prof. Dr. Lukács János egyetemi tanár, Dr. Koncsik Zsuzsanna adjunktus, Szilágyiné Dr. Biró Andrea egyetemi docens, Cserjésné Sutyák Ágnes tanszéki mérnök, Szántó Lászlóné ny. tanszéki mérnök, Szentpéteri Lászlóné müszaki szolgáltató.

\section{Irodalomjegyzék}

[1] https://www.arcanum.hu/hu/online-kiadvanyok/Lexikonok-magyar-eletrajzi-lexikon-7428D/zzs-787F8/zorkoczy-bela-788B3/

[2] http://kaleidoszkop.nih.gov.hu/kfi-hirek/-/asset_publisher/W8yXop3Tdrzr/content/a-nekifutregiszter-2014-felhivas-eredmenyei

[3] Anyagismeret és technológia III. (Anyagvizsgálati gyakorlatok). Szerk.: Gál, I.; Kóródy, L. Tankönyvkiadó, Budapest, 1992. (J 14-1413)

[4] Hőkezelés - Gyakorlati segédlet. Szerk.: Lizák, J. Nemzeti Tankönyvkiadó, Budapest, 1996. (J 14-1618)

[5] Pázsit, J.; Zolnay, G.; Sárvári, J.; Czabán, J.: Forgácsolás nélküli megmunkálás technológiája és szerszámai. Tankönyvkiadó, Budapest, 1967. (J 14-783)

[6] Zorkóczy, B.: Hegesztési anyagismeret. Felsőoktatási Jegyzetellátó Vállalat, Budapest, 1962.

[7] Romvári, P.: Hegesztéstechnológia - I. rész - A hegesztés fizikai és metallurgiai alapjai. Tankönyvkiadó, Budapest, 1989. (J 4-491 (1.))

[8] Dénes, M.: Gázhegesztés, lángvágás - Hegesztéstechnológia. Tankönyvkiadó, Budapest, 1962.

[9] Zorkóczy, B.: Metallográfia és anyagvizsgálat. Tankönyvkiadó, Budapest, 1978. (4. kiadás, ISBN 963173705 5)

[10] Komócsin, M.: Gépipari anyagismeret. COKOM Kft., Miskolc, 1997. (ISBN 963-04-8287-5)

[11] Tisza, M.: Metallográfia. Miskolci Egyetemi Kiadó, Miskolc, 1998. (ISBN 963661338 9)

[12] Balogh, A.; Sárvári, J.; Schäffer, J.; Tisza, M.: Mechanikai technológiák. Szerk.: Tisza, M. Miskolci Egyetem, Miskolc, 2003. (ISBN 963661571 3)

[13] Gál, I.; Kocsisné, B. M.; Lenkeyné, B. Gy.; Lukács, J.; Marosné, B. M.; Nagy, Gy.; Tisza, M.: Anyagvizsgálat. Szerk.: Tisza, M. Miskolci Egyetemi Kiadó, Miskolc, 2001. (ISBN 963661 $4520)$

[14] Gál, G.; Kiss, A.; Sárvári, J.; Tisza, M.: Képlékeny hidegalakítás. Szerk.: Sárvári, J. Nemzeti Tankönyvkiadó, Budapest, 1998. (9. kiadás, J 14-1362)

[15] Tisza, M.: Az anyagtudomány alapjai. Miskolci Egyetemi Kiadó, Miskolc, 2008. (ISBN 978 $9636618445)$

[16] Tisza, M.: Metal Forming. Miskolci Egyetem, Miskolc, 1996. 
[17] Tisza, M.: Physical Metallurgy for Engineers. American Society of Materials, Materials Park (OH), Amerikai Egyesült Államok, 2001. (ISBN 087170725X)

[18] Tisza, M.: Introduction to Materials Sciences. Miskolci Egyetem, Miskolc, 2003. (ISBN 963 6614377 )

[19] Tisza, M.: Physical Metallurgy for Engineers. Ahang-e-Ghalam Publishing House, Teherán, Irán, 2011. (ISBN 9786005452372)

[20] Artinger, I.; Kator, L.; Rovári, P.: Fémek technológiája. Szerk.: Gillemot, L. Müszaki Könyvkiadó, Budapest, 1971.

[21] Béres, L.; Unyi, B.: Sínek hegesztése. Müszaki Könyvkiadó, Budapest, 1978.

[22] Hegesztési kézikönyv. Főszerk.: Baránszky-Jób. I. Müszaki Könyvkiadó, Budapest, 1985. (ISBN 9631062457)

[23] Romvári, P.; Béres, L.: Javító és felrakóhegesztés. Műszaki Könyvkiadó, Budapest, 1984. (ISBN 9631057372)

[24] Béres, L.; Komócsin, M.: Acélok, öntöttvasak javító- és felrakóhegesztése. Monteditio Kft., Budapest, 1993. (ISBN 963-7690-05-0)

[25] Béres, L.; Csolák, A.; Kováts, A.: Anyagválasztási útmutató és példatár. Műszaki Könyvkiadó, Budapest, 1982. (ISBN 9631044009)

[26] Hegesztési zsebkönyv. Szerk.: Gáti, J. Müszaki Könyvkiadó, Budapest, 1995. (ISBN 963-160536-1)

[27] Hegesztés és rokon technológiák - Kézikönyv. Főszerk.: Szunyogh, L. Gépipari Tudományos Egyesület, Budapest, 2007. (ISBN 9789634209102)

[28] Béres, L.; Gáti, J.; Kovács, M.; Komócsin, M.; Gremsperger, G.: Hegesztési zsebkönyv. Szerk.: Gáti, J. Cokom Mérnökiroda Kft., Miskolc, 2003. (ISBN 963210742X)

[29] Gépgyártás, XLI. évfolyam, 11. szám, 2001. november. p. 40. A Miskolci Egyetem Mechanikai Technológiai Tanszéke oktatóinak publikációi. (ISSN 1587-4648)

[30] Gép, LXIII. évfolyam, 11. szám, 2012. p. 80. Innovációs gépészeti tervezés és technológiák. Innovatív anyagtechnológiák, számítógéppel segített technológiai folyamattervezés és folyamatmodellezés tudományos mühely. (ISSN 0016-8572)

[31] Gép, LXIV. évfolyam, 8. szám, 2013. p. 64. AUTOTECH - „Jármüipari anyagfejlesztések: célzott alapkutatás az alakíthatóság, hőkezelés és hegeszthetöség témaköreiben" TÁMOP4.2.2.A-11/1/KONV-2012-0029. www.autotech.uni-miskolc.hu Anyagszerkezettani és Anyagtechnológiai Intézet különszáma. (ISSN 0016-8572)

[32] http://web.alt.uni-miskolc.hu/hikomp/

[33] http://www.zrva.hu/mlrret.html

[34] http://kivalosagi-kozpontok.uni-miskolc.hu/

[35] Polimer mátrixú kompozittal erősített hibrid csövek integritása - GVOP-3.1.1.-2004-050215/3.0. Szerk.: Lukács, J. Miskolci Egyetemi Kiadó, Miskolc, 2008. (ISBN 9789636618315)

[36] Lukács, J.; Nagy, Gy.; Török, I.: Szemelvények az élettartam gazdálkodás témaköréből. Szerk.: Lukács, J. Miskolci Egyetem, Miskolc, 2009. (ISBN 9789636618902)

[37] Lukács, J.; Nagy, Gy.; Harmati, I.; Koritárné, F. R.; Kuzsella, Lné. K. Zs.: Szemelvények a mérnöki szerkezetek integritása témaköréből. Szerk.: Lukács, J. Miskolci Egyetem, Miskolc, 2012. (ISBN 978-963-358-000-4)

[38] http://www.autotech.uni-miskolc.hu/

[39] Hegeszthetőség és a hegesztett kötések tulajdonságai. Szerk.: Balogh, A.; Lukács, J.; Török, I.; Miskolci Egyetem, Miskolc, 2015. p. 324. (ISBN 978-963-358-081-3) 
[40] Képlékenyalakítás a jármüiparban. Szerk.: Tisza, M. Miskolci Egyetem, Miskolc, 2015. p. 294. (ISBN 978-963-358-082-0)

[41] Nitridálás - korszerủ eljárások és vizsgálati módszerek. Szerk.: Kocsisné, Baán, M., Marosné, Berkes, M.; Szilágyiné, Biró, A. Miskolci Egyetem, Miskolc, 2015. p. 296. (ISBN 978-963358-080-6)

[42] Edzőközegek korszerü vizsgálati módszerei. Szerk.: Felde, I.; Kerekes, G.; Mucsi, A. Miskolci Egyetem, Miskolc, 2015. p. 94. (ISBN 978-963-358-083-7)

[43] Fejezetek a nemfémes anyagok legújabb jármüipari kutatási területeiből. Szerk.: Zsoldos, I. Széchenyi István Egyetem, Győr, 2015. p. 330. (ISBN 978-615-5391-36-1)

[44] Technológiai maradó feszültségek modellezése és mérése. Szerk.: Lenkeyné Biró, Gy. Bay Zoltán Alkalmazott Kutatási Közhasznú Nonprofit Kft., Miskolc, 2015. p. 198. (ISBN 9789638812254 )

[45] A Nehézipari Műszaki Egyetem Mechanikai Technológiai Tanszéke oktatóinak és kutatóinak szakirodalmi munkássága 1950-1985. Szerk.: Tisza, Mné. Nehézipari Műszaki Egyetem, Sokszorosító Üzem, Miskolc, 1985. p. 137. (Met. 86-40. N.M.E.)

[46] A Miskolci Egyetem Mechanikai Technológiai Tanszékének tudományos tevékenysége 19861990. Felelős szerk.: Török, I. Miskolci Egyetem, Sokszorosító Üzem, Miskolc, 1991. p. 82. (Met.91-660/ME)

[47] A Miskolci Egyetem Mechanikai Technológiai Tanszékének tudományos tevékenysége 19911995. Felelős szerk.: Tóth, L.; Török, I. Miskolci Egyetem, Sokszorosító Üzem, Miskolc, 1996. p. 61. (Met. 96-718/ME.)

[48] 60 éves a Mechanikai Technológiai Tanszék 1950-2010. Felelős szerk.: Török, I. Miskolci Egyetem, Sokszorosító Üzem, Miskolc, 2011. p. 93. (Met. 2011-41/ME.)

[49] 50 éves a Gépészmérnöki Kar. Prof. Dr. Romvári Pál 70 éves. Mechanikai Technológiai szaknap a Gépészmérnöki Kar jubileumi rendezvényei sorozatában. Miskolci Egyetem, Sokszorosító Üzem, Miskolc, 1999. p. 47. (Met. 700-99/ME)

[50] Jubileumi Tudományos Ülés Béres Lajos, Kovács Ferenc és Pirkó József születésének 70. évfordulója alkalmából. Felelős szerk.: Komócsin, M. Miskolci Egyetem, Sokszorosító Üzem, Miskolc, 2002. p. 35. (Met.2002-700/ME.)

[51] https://www.mtmt.hu/

[52] Zorkóczy Béla Tudományos Emlékülés, Miskolci Egyetem Mechanikai Technológiai Tanszék, Miskolc, 1996. augusztus 30-31. Észak-Magyarországi Gazdaság - Kultúra - Tudomány, 1996. 7-8. p. B1-B28. (ISSN 1219-9540)

[53] Gépgyártástechnológia, XL. évfolyam, 8. szám, 2000. augusztus. p. 56. 50 éves a Miskolci Egyetem Mechanikai Technológiai Tanszéke 1950-2000. (HU ISSN 0016-8580)

[54] Gép, LXII. évfolyam, 4. szám, 2011. p. 60. 60 éves a Miskolci Egyetem Mechanikai Technológiai Tanszéke 1950-2010, 50 éves a Hegesztő Szakmérnök-képzés 1961-2011. (ISSN 00168572)

[55] Gép, LXVII. évfolyam, 1-2. szám, 2016. p. 86.65 éves a Miskolci Egyetem Mechanikai Technológiai Tanszéke (ma: Anyagszerkezettani és Anyatechnológiai Intézet) 1950-2015, 55 éves a Hegesztő Szakmérnök-képzés Miskolcon, 40 éve hunyt el Dr. Zorkóczy Béla, tanszékalapító professzor. (ISSN 0016-8572)

[56] 50 éves a Hegesztő Szakmérnök-képzés 1961-2011. Felelős szerk.: Török, I. Miskolci Egyetem, Sokszorosító Üzem, Miskolc, 2011. p. 47. (Met. 2011-40/ME.) 
[57] Tóth, L.: Prof. emeritus Dr. Romvári Pál 70 éves. Anyagvizsgálók lapja, 9. évfolyam, 3. szám, 1999. p. 123-125. (ISSN 1215-8410)

[58] Tóth, L.: Dr. Romvári Pál 1929-2008. Anyagvizsgálók lapja, 19. évfolyam, 1. szám, 2009. p. 46-48. (HU ISSN 1787-5072)

[59] http://kvt96.lib.uni-miskolc.hu/muzeum/kiallitas/romvari/

[60] https://multiscience.uni-miskolc.hu/files/634/programfuzet_2016.pdf

[61] https://multiscience.uni-miskolc.hu/files/5142/2019_programfuzet.pdf 